\title{
Penerapan Data Mining Pada Ekspor Buah-Buahan Menurut Negara Tujuan Menggunakan K-Means Clustering
}

\author{
Application of Data mining on Fruit Exports by Destination Country Using K-Means
} Clustering

\author{
Agus Perdana Windarto \\ Program Studi Sistem Informasi, STIKOM Tunas Bangsa \\ Jln. Jendral Sudirman Blok A- No.1/2/3 Pematangsiantar, (0622)- 22431 \\ e-mail: agus.perdana@amiktunasbangsa.ac.id
}

\begin{abstract}
Abstrak
Indonesia adalah salah satu negara pengekspor ke negara-negara maju dan berkembang. Tujuan dari eksportir adalah untuk dapat memperoleh keuntungan. Penelitian ini membahas tentang Penerapan Datamining Pada Ekspor Buah-Buahan Menurut Negara Tujuan Menggunakan K-Means Clustering Method. Sumber data penelitian ini dikumpulkan berdasarkan dokumen-dokumen keterangan ekspor impor yang dihasilkan oleh Direktorat Jenderal Bea dan Cukai. Data yang digunakan dalam penelitian ini adalah data dari tahun 20022015 yang terdiri dari 11. Variable yang digunakan (1) jumlah ekspor berat bersih (netto) dan (2) nilai Free On Board (FOB). Data akan diolah dengan melakukan clustering dalam 3 cluster yaitu cluster tingkat ekspor tinggi, cluster tingkat ekspor sedang dan cluster tingkat ekspor rendah. Centroid data untuk cluster tingkat ekspor tinggi 904.276,5, Centroid data untuk cluster tingkat ekspor sedang 265.501 dan Centroid data untuk cluster tingkat ekspor rendah 34.280,1. Sehingga diperoleh penilaian berdasarkan indeks ekspor buah-buahan dengan 2 negara cluster tingkat ekspor tinggi yakni India dan Pakistan, 3 negara cluster tingkat ekspor sedang yakni Singapura, Bangladesh dan Negara lainnya dan 6 negara cluster tingkat ekspor rendah yakni Hongkong, Tiongkok, Malaysia, Nepal, Vietnam dan Iran. Hal ini dapat menjadi masukkan kepada pemerintah, negara yang menjadi prioritas tertinggi pada kegiatan ekspor buah-buahan berdasarkan klaster yang telah dilakukan.
\end{abstract}

Kata kunci--Clustering, K-Means, Data Mining, ekspor, buah-buahan

\begin{abstract}
Indonesia is one of the exporting countries to the developed and developing countries. The purpose of the exporter is to be able to make a profit. This study discusses the Application of Datamining on Fruit Exports by Destination Country Using K-Means Clustering Method. The data sources of this study were collected based on import export information documents produced by the Directorate General of Customs and Excise. The data used in this study is data from 2002-2015 which consists of 11. Variables used (1) the number of net weight exports (net) and (2) the value of Free On Board (FOB). The data will be processed by clustering in 3 clusters, namely high export level clusters, medium export level clusters and low export level clusters. Centroid data for high export-level clusters is 904.276.5, Centroid data for export level clusters is 265,501 and Centroid data for low export level clusters is 34.280.1. The result is an assessment based on the index of export of fruits with 2 countries of high export level clusters of India and Pakistan, 3 medium-level clusters of moderate exports of Singapore, Bangladesh and other countries and 6 countries of low export level clusters ie Hongkong, China, Malaysia, Nepal, Vietnam and Iran. This can be an insert to the government, the country that is the highest priority in the export of fruits based on the cluster that has been done.
\end{abstract}

Keywords--Clustering, K-Means, Data Mining, exports, fruits 


\section{PENDAHULUAN}

Indonesia adalah salah satu negara pengekspor ke negara-negara maju dan berkembang. Tujuan dari eksportir adalah untuk dapat memperoleh keuntungan. Harga barang-barang yang diekspor di luar negeri tersebut lebih mahal dibandingkan dengan yang di dalam negeri. Dengan adanya ekspor tersebut, pemerintah juga memperoleh pendapatan yang berupa suatu devisa. Semakin banyak ekspor makan akan semakin besar devisa yang diperoleh oleh negara. Barangbarang yang diekspor oleh Indonesia terdiri dari dua macam, yaitu minyak bumi dan gas alam (migas) serta juga nonmigas. Barang-barang yang termasuk dengan migas antara lain ialah minyak tanah, bensin, solar, serta elpiji. Adapun barang-barang yang termasuk nonmigas ialah (a) Hasil pertanian serta juga perkebunan. Contohnya, karet, kopi, dll. (b) Hasil laut terutama ialah ikan dan juga kerang. (c) Hasil industri. Contohnya kayu lapis,minyak kelapa dll. (d) Hasil tambang nonmigas. Contohnya ialah bijih nekel, bijih tembaga, serta batubara. Berdasarkan jenis ekspor, penelitian ini membahas tentang ekspor non migas yakni hasil pertanian dan perkebunan. Objek penelitian yang dilakukan adalah menitik beratkan pada ekspor buah-buahan berdasarkan Negara tujuan. Penelitian ini menggunakan Datamining dengan analisa klaster.

Analisis klaster merupakan suatu teknik multivariat dengan tujuan utama mengelompokkan objek-objek berdasarkan karakteristik yang dimiliki. Sekarang ini analisis klaster telah banyak diaplikasikan dalam berbagai bidang yang ditulis dalam berbagai penelitian dan jurnal [1]. Dalam metode clustering konsep utama yang ditekankan adalah pencarian pusat cluster secara iteratif, dimana pusat cluster ditentukan berdasarkan jarak minimum setiap data pada pusat cluster [2]. Data yang digunakan dalam penelitian ini berdasarkan dokumendokumen keterangan ekspor impor yang dihasilkan oleh Direktorat Jenderal Bea dan Cukai melalui situs https://www.bps.go.id. Dalam hal ini peneliti mengangkat topik ekspor buahbuahan berdasarkan negara tujuan dimana proses metode yang dilakukan adalah clustering. Hasil dari cluster dapat dijadikan masukan bagi negara indonesia sebagai bentuk pemetaan terhadap negara tujuan. Proses pemetaan dapat di cluster kedalam 3 (tiga) cluster yakni produksi ekspor tertinggi, produksi ekspor sedang dan produksi ekspor rendah.

Endang Sugiharti [3] pada penelitiannya melakukan clustering data dosen terkait kegiatan dan kinerjanya sesuai dengan pelaksanaan dan tanggung jawab meggunanakan metode K-Means. Cluster dalam penelitian tersebut kedalam cluster Networking, Software Engineering, dan E-Learning. Metode clustering yang digunakan dalam penelitian ini adalah metode KMeans. K-Means dapat juga diartikan merupakan metode Clustering yang termasuk dalam pendekatan partitioning. Algoritma K-Means merupakan model centroid. Mode centroid adalah model yang menggunakan centroid untuk membuat cluster. Centroid adalah titik tengah suatu cluster. Centroid berupa nilai. Centroid digunakan untuk menghitung jarak suatu objek data terhadap centroid. Suatu objek data termasuk dalam cluster jika memiliki jarak terpendek terhadap centroid cluster tersebut. Algoritma K-Means dapat diartikan sebagai algoritma pembelajaran yang sederhana untuk memecahkan suatu permasalahan pengelompokkan yang bertujuan untuk meminimalkan kesalahan ganda [4]. Tujuan dari penelitian ini adalah menerapkan k-means dalam mengcluster ekspor buah-buahan berdasarkan negara tujuan. Hal ini dapat menjadi masukkan kepada pemerintah, negara yang menjadi prioritas tertinggi pada kegiatan ekspor buah-buahan berdasarkan klaster yang telah dilakukan.

\section{METODE PENELITIAN}

Dalam penelitian ini metode yang digunakan yaitu metode data mining sebagai berikut. (a) Tahap pengumpulan data, (b) Tahap pengolahan data, (c) Tahap Clustering dan (d) Tahap Analisis [5]. Tahapan dalam metode tersebut dijelaskan lebih lanjut sebagai berikut: 


\subsection{Tahap Pengumpulan Data}

Dalam penerapan datamining produksi ekspor buah buahan menurut negara tujuan, diperlukan data terkait tentang hal itu. Sumber data penelitian diperoleh dari data yang dikumpulkan berdasarkan dokumen-dokumen keterangan ekspor impor yang dihasilkan oleh Direktorat Jenderal Bea dan Cukai melalui situs https://www.bps.go.id . Selain itu sejak tahun 2015 data ekspor juga berasal dari PT. Pos Indonesia, catatan instansi lain di perbatasan, dan hasil survei perdagangan lintas batas laut. Data yang digunakan dalam penelitian ini adalah data Ekspor Buah-buahan Menurut Negara Tujuan Utama dari tahun 2002-2015 yang terdiri dari 11 negara yakni Hongkong, Tiongkok, Singapura, Malaysia, Nepal, Vietnam, India, Pakistan, Bangladesh, Iran dan Negara Lainya. Varibale yang digunakan (1) jumlah ekspor berat bersih (netto) dan (2) nilai Free On Board (FOB. Data akan diolah dengan melakukan clustering ekspor buah-buahan berdasarkan negara tujuan utama dalam 3 cluster yakni cluster tingkat ekspor tinggi, cluster tingkat ekspor sedang dan cluster tingkat ekspor rendah

\subsection{Tahap Pengolahan Data}

Data yang telah diperolah akan diolah terlebih dahulu untuk dapat diclustering. Dalam tahap sebelumnya, data setiap negara tujuan ekspor buah buahan akan dijumlah setiap aspeknya sehingga pada tahapan ini sudah diperoleh perhitungan nilai yang akan diproses pada tahap clustering.

\subsection{Tahap Clustering}

Clustering merupakan klasifikasi tanpa pengawasan dan merupakan proses partisi sekumpulan objek data dari satu set menjadi beberapa kelas. Hal ini dapat dilakukan dengan menerapkan berbagai persamaan dan langkah-langkah mengenai jarak algoritma, yaitu dengan Euclidean Distance [6]. Analisis kluster ialah metode yang dipakai untuk membagi rangkaian data menjadi beberapa grup berdasarkan kesamaan-kesamaan yang telah ditentukan sebelumnya [3]. Dalam menentukan cluster berdasarkan data yang telah tersedia, dibutuhkan sebuah flowchart untuk memudahkan dalam menentukan alur perhitungan sebagai alur untuk menemukan hasil dari penerapan cluster terhadap data yang akan diproses. Berikut adalah flowchart dalam menentukan cluster dengan K-Means [7].

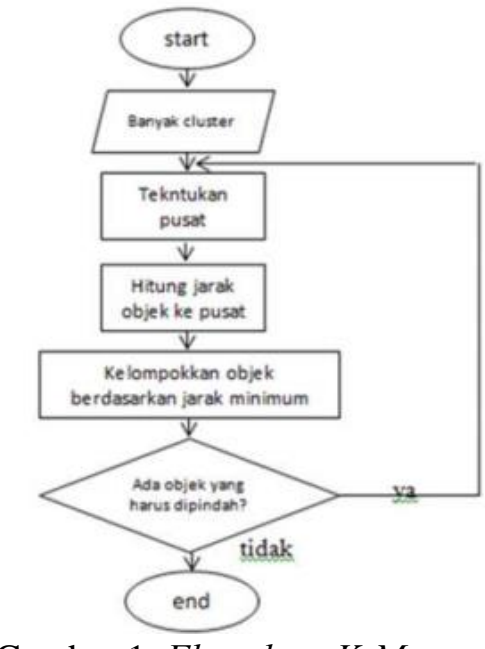

Gambar 1. Flowchart K-Means

\subsection{Tahap Analisis}

Pada tahapan ini dilakukan analisis data ekspor buah buahan menurut negara tujuan aplikasi tool. Rapid Minner. RapidMiner adalah sebuah lingkungan machine learning data mining, text mining dan predictive analytics [8]. Data yang diperoleh diolah dengan menggunakan perhitungan bobot dari tiap indeks. Pada tahapan sebelumnya, telah ditentukan 
akan dicluster ke dalam 3 cluster yakni cluster tingkat ekspor tinggi, cluster tingkat ekspor sedang dan cluster tingkat ekspor rendah. Pada tahapan inilah akan dianalisis hasilnya.

\section{HASIL DAN PEMBAHASAN}

Dalam melakukan clustering, data yang diperoleh akan dihitung terlebih dahulu berdasarkan jumlah ekspor buah buahan pada tahun 2002-2015 berdasarkan negara tujuan. Hasil penjumlahan berdasarkan 2 kriteria penilaian yakni berat bersih (netto) dan nilai FOB seperti yang ditunjukkan pada tabel 1.

Tabel 1. Data Ekspor Buah-buahan Menurut Negara Tujuan Utama, 2002-2015

\begin{tabular}{|c|c|c|c|c|c|c|c|c|c|c|c|c|c|c|c|}
\hline $\begin{array}{l}\text { Negara } \\
\text { Tujuan }\end{array}$ & 2002 & 2003 & 2004 & 2005 & 2006 & 2007 & 2008 & 2009 & 2010 & 2011 & 2012 & 2013 & 2014 & 2015 & Total \\
\hline & \multicolumn{15}{|c|}{ Berat Bersih (Ton) } \\
\hline Hongkong & $\begin{array}{r}4.876 \\
8\end{array}$ & $\begin{array}{r}8.213 \\
8\end{array}$ & $\begin{array}{r}2.830 \\
7\end{array}$ & $\begin{array}{r}4.478 \\
2\end{array}$ & $\begin{array}{r}1.565, \\
2\end{array}$ & $\begin{array}{r}3.590 \\
4\end{array}$ & $\begin{array}{r}3.770 \\
3\end{array}$ & $\begin{array}{r}5.938 \\
9\end{array}$ & $\begin{array}{r}5.926 \\
3\end{array}$ & $\begin{array}{r}2.831, \\
3\end{array}$ & $\begin{array}{r}9.770 \\
7\end{array}$ & $\begin{array}{r}2.023, \\
8\end{array}$ & $1.614,1$ & $6.800,0$ & $64.230,5$ \\
\hline Tiongkok1) & 518,7 & 996,2 & $\begin{array}{r}1.140, \\
6\end{array}$ & $\begin{array}{r}5.085 \\
3\end{array}$ & $\begin{array}{r}5.713 \\
7\end{array}$ & $\begin{array}{r}6.448 \\
7\end{array}$ & $\begin{array}{r}6.511, \\
8\end{array}$ & $\begin{array}{r}4.905 \\
4\end{array}$ & $\begin{array}{r}6.677 \\
4\end{array}$ & $\begin{array}{r}8.142, \\
6\end{array}$ & $\begin{array}{r}10.68 \\
8,9\end{array}$ & $\begin{array}{r}4.825 \\
3\end{array}$ & $\begin{array}{r}20.189 \\
7\end{array}$ & $9.792,4$ & $91.636,7$ \\
\hline Singapura & $\begin{array}{r}1.455 \\
9\end{array}$ & $\begin{array}{r}3.538 \\
0\end{array}$ & $\begin{array}{r}1.849 \\
3\end{array}$ & $\begin{array}{r}1.080, \\
6\end{array}$ & $\begin{array}{r}5.586 \\
3\end{array}$ & $\begin{array}{r}9.824 \\
4\end{array}$ & $\begin{array}{r}19.50 \\
0,0\end{array}$ & $\begin{array}{r}31.56 \\
4,6\end{array}$ & $\begin{array}{r}39.83 \\
9,2\end{array}$ & $\begin{array}{r}31.920 \\
, 4\end{array}$ & $\begin{array}{r}34.31 \\
9,8\end{array}$ & $\begin{array}{r}22.54 \\
0,4\end{array}$ & $\begin{array}{r}19.183, \\
6\end{array}$ & $\begin{array}{r}18.350 \\
9\end{array}$ & $240.553,4$ \\
\hline Malaysia & $\begin{array}{r}3.852, \\
7\end{array}$ & $\begin{array}{r}6.004 \\
4\end{array}$ & $\begin{array}{r}6.417 \\
6\end{array}$ & $\begin{array}{r}4.463 \\
9\end{array}$ & $\begin{array}{r}3.491, \\
4\end{array}$ & $\begin{array}{r}8.967, \\
0\end{array}$ & $\begin{array}{r}7.150 \\
1\end{array}$ & $\begin{array}{r}4.749 \\
9\end{array}$ & $\begin{array}{r}5.092 \\
7\end{array}$ & $\begin{array}{r}4.964 \\
1\end{array}$ & $\begin{array}{r}5.434, \\
8\end{array}$ & $\begin{array}{r}10.18 \\
0,4\end{array}$ & $\begin{array}{r}11.582 \\
4\end{array}$ & $\begin{array}{r}29.465 \\
3\end{array}$ & $111.816,7$ \\
\hline Nepal & 36,0 & $\begin{array}{r}5.010 \\
7\end{array}$ & $\begin{array}{r}3.359 \\
4\end{array}$ & $\begin{array}{r}5.918, \\
6\end{array}$ & $\begin{array}{r}6.103 \\
7\end{array}$ & $\begin{array}{r}16.375 \\
, 6\end{array}$ & $\begin{array}{r}15.01 \\
5,9\end{array}$ & $\begin{array}{r}14.47 \\
5,3\end{array}$ & $\begin{array}{r}16.18 \\
9,0\end{array}$ & $\begin{array}{r}8.797 \\
0\end{array}$ & $\begin{array}{r}5.104 \\
1\end{array}$ & $\begin{array}{r}11.02 \\
4,8\end{array}$ & $9.440,6$ & $\begin{array}{r}14.502 \\
6\end{array}$ & $131.353,3$ \\
\hline Vietnam & 0,0 & 81,9 & 621,8 & $\begin{array}{r}2.135 \\
1\end{array}$ & $\begin{array}{r}7.058 \\
8\end{array}$ & $\begin{array}{r}6.886 \\
7\end{array}$ & $\begin{array}{r}3.571 \\
6\end{array}$ & 768,9 & 474,6 & 352,7 & $\begin{array}{r}2.327 \\
7\end{array}$ & $\begin{array}{r}2.509 \\
7\end{array}$ & $3.467,8$ & $4.022,8$ & $34.280,1$ \\
\hline India & $\begin{array}{r}14.47 \\
2,3\end{array}$ & $\begin{array}{r}26.840 \\
, 9\end{array}$ & $\begin{array}{r}45.20 \\
6,2\end{array}$ & $\begin{array}{r}61.134 \\
, 9\end{array}$ & $\begin{array}{r}89.43 \\
4,2\end{array}$ & $\begin{array}{r}67.845 \\
, 0\end{array}$ & $\begin{array}{r}70.67 \\
2,7\end{array}$ & $\begin{array}{r}66.75 \\
6,5\end{array}$ & $\begin{array}{r}54.77 \\
3,7\end{array}$ & $\begin{array}{r}19.487 \\
, 4\end{array}$ & $\begin{array}{r}23.67 \\
5,1\end{array}$ & $\begin{array}{r}36.70 \\
5,4\end{array}$ & $\begin{array}{r}31.444 \\
4\end{array}$ & $\begin{array}{r}29.859 \\
0\end{array}$ & $638.307,7$ \\
\hline Pakistan & $\begin{array}{r}54.26 \\
1,6\end{array}$ & $\begin{array}{r}10.097 \\
, 3\end{array}$ & $\begin{array}{r}13.14 \\
2,3\end{array}$ & $\begin{array}{r}49.148 \\
, 8\end{array}$ & $\begin{array}{r}53.29 \\
7,2\end{array}$ & $\begin{array}{r}61.882 \\
, 6\end{array}$ & $\begin{array}{r}64.64 \\
8,6\end{array}$ & $\begin{array}{r}73.02 \\
6,2\end{array}$ & $\begin{array}{r}73.77 \\
3,6\end{array}$ & $\begin{array}{r}71.948 \\
, 9\end{array}$ & $\begin{array}{r}87.01 \\
3,3\end{array}$ & $\begin{array}{r}91.18 \\
8,3\end{array}$ & $\begin{array}{r}101.27 \\
5,1\end{array}$ & $\begin{array}{r}99.572, \\
7\end{array}$ & $904.276,5$ \\
\hline Bangladesh & 993,3 & $\begin{array}{r}7.712, \\
2\end{array}$ & $\begin{array}{r}15.18 \\
5,4\end{array}$ & $\begin{array}{r}22.845 \\
, 7\end{array}$ & $\begin{array}{r}2.882, \\
2\end{array}$ & $\begin{array}{r}19.047 \\
, 3\end{array}$ & $\begin{array}{r}16.47 \\
2,3\end{array}$ & $\begin{array}{r}10.35 \\
3,1\end{array}$ & $\begin{array}{r}28.24 \\
9,4\end{array}$ & $\begin{array}{r}53.787 \\
, 2\end{array}$ & $\begin{array}{r}62.07 \\
4,4\end{array}$ & $\begin{array}{r}50.98 \\
8,5\end{array}$ & $\begin{array}{r}51.719 \\
1\end{array}$ & $\begin{array}{r}23.403 \\
0\end{array}$ & $365.713,1$ \\
\hline Iran & 0,0 & $\begin{array}{r}17.154 \\
, 1\end{array}$ & $\begin{array}{r}38.42 \\
8,9\end{array}$ & $\begin{array}{r}3.562, \\
2\end{array}$ & $\begin{array}{r}2.900, \\
0\end{array}$ & $\begin{array}{r}1.704 \\
0\end{array}$ & $\begin{array}{r}1.693, \\
7\end{array}$ & - & 18,0 & 725,0 & - & - & - & 18,0 & $66.203,9$ \\
\hline Lainnya & $\begin{array}{r}13.36 \\
6,6\end{array}$ & $\begin{array}{r}24.572 \\
, 3\end{array}$ & $\begin{array}{r}13.29 \\
5,0\end{array}$ & $\begin{array}{r}3.964, \\
3\end{array}$ & $\begin{array}{r}5.893, \\
2\end{array}$ & $\begin{array}{r}4.624, \\
8\end{array}$ & $\begin{array}{r}4.962 \\
1\end{array}$ & $\begin{array}{r}3.474 \\
4\end{array}$ & $\begin{array}{r}3.277 \\
7\end{array}$ & $\begin{array}{r}5.993, \\
0\end{array}$ & $\begin{array}{r}5.848 \\
7\end{array}$ & $\begin{array}{r}14.95 \\
7,2\end{array}$ & $\begin{array}{r}49.187, \\
5\end{array}$ & $\begin{array}{r}118.72 \\
2,2\end{array}$ & $272.139,0$ \\
\hline & \multicolumn{15}{|c|}{ Nilai FOB (Ribu US\$) } \\
\hline Hongkong & $\begin{array}{r}4.631, \\
8\end{array}$ & $\begin{array}{r}8.691, \\
7\end{array}$ & $\begin{array}{r}4.034, \\
5\end{array}$ & $\begin{array}{r}3.938 \\
2\end{array}$ & $\begin{array}{r}1.015, \\
1\end{array}$ & $\begin{array}{r}2.137 \\
2\end{array}$ & $\begin{array}{r}2.473 \\
0\end{array}$ & $\begin{array}{r}4.247 \\
2\end{array}$ & $\begin{array}{r}4.771 \\
1\end{array}$ & $\begin{array}{r}2.390 \\
0\end{array}$ & $\begin{array}{r}7.364 \\
0\end{array}$ & $\begin{array}{r}1.803, \\
9\end{array}$ & $1.524,2$ & $3.576,7$ & $52.598,6$ \\
\hline Tiongkok1) & 161,3 & 288,1 & 475,9 & $\begin{array}{r}2.784, \\
2\end{array}$ & $\begin{array}{r}2.738 \\
3\end{array}$ & $\begin{array}{r}2.912, \\
8\end{array}$ & $\begin{array}{r}3.225 \\
7\end{array}$ & $\begin{array}{r}2.472 \\
8\end{array}$ & $\begin{array}{r}5.339 \\
8\end{array}$ & $\begin{array}{r}7.243 \\
2\end{array}$ & $\begin{array}{r}10.74 \\
5,7\end{array}$ & $\begin{array}{r}4.130 \\
5\end{array}$ & $\begin{array}{r}15.615, \\
5\end{array}$ & $9.198,2$ & $67.332,0$ \\
\hline Singapura & 959,2 & $\begin{array}{r}1.444, \\
6\end{array}$ & 801,2 & 792,6 & $\begin{array}{r}3.474 \\
6\end{array}$ & $\begin{array}{r}5.713 \\
4\end{array}$ & $\begin{array}{r}12.06 \\
1,0\end{array}$ & $\begin{array}{r}13.74 \\
5,9\end{array}$ & $\begin{array}{r}23.47 \\
2,5\end{array}$ & $\begin{array}{r}37.850 \\
, 5\end{array}$ & $\begin{array}{r}26.10 \\
5,2\end{array}$ & $\begin{array}{r}17.81 \\
1,6\end{array}$ & $\begin{array}{r}23.902, \\
9\end{array}$ & $\begin{array}{r}25.194, \\
5\end{array}$ & $193.329,7$ \\
\hline Malaysia & 870,6 & $\begin{array}{r}1.496 \\
3\end{array}$ & $\begin{array}{r}2.778 \\
1\end{array}$ & $\begin{array}{r}2.017, \\
8\end{array}$ & $\begin{array}{r}1.514, \\
7\end{array}$ & $\begin{array}{r}2.984 \\
6\end{array}$ & $\begin{array}{r}2.294 \\
1\end{array}$ & $\begin{array}{r}1.611, \\
3\end{array}$ & $\begin{array}{r}1.593 \\
3\end{array}$ & $\begin{array}{r}2.062, \\
7\end{array}$ & $\begin{array}{r}2.264, \\
2\end{array}$ & $\begin{array}{r}5.316, \\
3\end{array}$ & $5.034,3$ & $\begin{array}{r}11.919 \\
6\end{array}$ & $43.757,9$ \\
\hline Nepal & 10,5 & $\begin{array}{r}1.508 \\
0\end{array}$ & $\begin{array}{r}1.143, \\
5\end{array}$ & $\begin{array}{r}2.102 \\
5\end{array}$ & $\begin{array}{r}2.446 \\
4\end{array}$ & $\begin{array}{r}6.673, \\
8\end{array}$ & $\begin{array}{r}7.043 \\
9\end{array}$ & $\begin{array}{r}6.103 \\
8\end{array}$ & $\begin{array}{r}7.334 \\
6\end{array}$ & $\begin{array}{r}7.403 \\
5\end{array}$ & $\begin{array}{r}3.616, \\
2\end{array}$ & $\begin{array}{r}8.788, \\
6\end{array}$ & $9.574,1$ & $\begin{array}{r}16.155 \\
3\end{array}$ & $79.904,7$ \\
\hline Vietnam & 0,0 & 50,0 & 678,0 & $\begin{array}{r}1.952, \\
0\end{array}$ & $\begin{array}{r}4.229 \\
6\end{array}$ & $\begin{array}{r}6.376, \\
6\end{array}$ & $\begin{array}{r}2.830 \\
3\end{array}$ & 387,3 & 193,4 & 247,8 & $\begin{array}{r}1.387 \\
6\end{array}$ & $\begin{array}{r}1.853 \\
4\end{array}$ & $3.172,7$ & $4.012,6$ & $27.371,3$ \\
\hline India & $\begin{array}{r}5.547 \\
1\end{array}$ & $\begin{array}{r}8.913, \\
2\end{array}$ & $\begin{array}{r}17.67 \\
1,8\end{array}$ & $\begin{array}{r}26.050 \\
, 7\end{array}$ & $\begin{array}{r}43.58 \\
7,0\end{array}$ & $\begin{array}{r}34.681 \\
, 7\end{array}$ & $\begin{array}{r}40.19 \\
9,6\end{array}$ & $\begin{array}{r}29.81 \\
5,7\end{array}$ & $\begin{array}{r}24.74 \\
6,3\end{array}$ & $\begin{array}{r}12.249 \\
, 5\end{array}$ & $\begin{array}{r}18.23 \\
3,7\end{array}$ & $\begin{array}{r}29.24 \\
2,6\end{array}$ & $\begin{array}{r}33.396, \\
8\end{array}$ & $\begin{array}{r}39.369 \\
3\end{array}$ & $363.705,0$ \\
\hline Pakistan & $\begin{array}{r}13.31 \\
8,0\end{array}$ & $\begin{array}{r}2.795 \\
8\end{array}$ & $\begin{array}{r}6.879 \\
8\end{array}$ & $\begin{array}{r}22.845 \\
, 0\end{array}$ & $\begin{array}{r}30.73 \\
6,6\end{array}$ & $\begin{array}{r}38.435 \\
, 9\end{array}$ & $\begin{array}{r}40.98 \\
0,0\end{array}$ & $\begin{array}{r}37.66 \\
0,5\end{array}$ & $\begin{array}{r}44.01 \\
8,8\end{array}$ & $\begin{array}{r}56.351 \\
, 4\end{array}$ & $\begin{array}{r}67.23 \\
3,9\end{array}$ & $\begin{array}{r}68.76 \\
8,3\end{array}$ & $\begin{array}{r}91.756, \\
6\end{array}$ & $\begin{array}{r}98.208 \\
1\end{array}$ & $619.988,7$ \\
\hline Bangladesh & 259,6 & $\begin{array}{r}1.885 \\
4\end{array}$ & $\begin{array}{r}4.644 \\
4\end{array}$ & $\begin{array}{r}6.782 \\
1\end{array}$ & $\begin{array}{r}1.623, \\
6\end{array}$ & $\begin{array}{r}8.743 \\
1\end{array}$ & $\begin{array}{r}9.892, \\
3\end{array}$ & $\begin{array}{r}5.950, \\
8\end{array}$ & $\begin{array}{r}17.16 \\
7,1\end{array}$ & $\begin{array}{r}40.451 \\
, 4\end{array}$ & $\begin{array}{r}40.63 \\
9,4\end{array}$ & $\begin{array}{r}36.61 \\
1,2\end{array}$ & $\begin{array}{r}59.087 \\
9\end{array}$ & $\begin{array}{r}29.346 \\
0\end{array}$ & $263.084,3$ \\
\hline Iran & 0,0 & $\begin{array}{r}6.232, \\
9\end{array}$ & $\begin{array}{r}12.77 \\
8,9\end{array}$ & $\begin{array}{r}1.225, \\
0\end{array}$ & 933,8 & 587,8 & 780,9 & - & 9,5 & 435,2 & - & - & - & 31,0 & $23.015,0$ \\
\hline Lainnya & $\begin{array}{r}19.96 \\
7,6\end{array}$ & $\begin{array}{r}20.917 \\
, 9\end{array}$ & $\begin{array}{r}9.464, \\
3\end{array}$ & $\begin{array}{r}3.152 \\
8\end{array}$ & $\begin{array}{r}4.684 \\
9\end{array}$ & $\begin{array}{r}3.923 \\
3\end{array}$ & $\begin{array}{r}3.621, \\
7\end{array}$ & $\begin{array}{r}2.263 \\
2\end{array}$ & $\begin{array}{r}3.129 \\
1\end{array}$ & $\begin{array}{r}6.341 \\
5\end{array}$ & $\begin{array}{r}5.901 \\
6\end{array}$ & $\begin{array}{r}12.27 \\
8,0\end{array}$ & $\begin{array}{r}59.138, \\
5\end{array}$ & $\begin{array}{r}131.67 \\
3,8\end{array}$ & $286.458,2$ \\
\hline
\end{tabular}

Sumber : Badan Pusat Statistik, url : https://www.bps.go.id

Data tersebut kemudian diakumulasikan berdasarkan 2 kriteria yakni berat bersih (netto) dan (2) nilai Free On Board (FOB) seperti yang ditunjukkan pada tabel 2 berikut:

Tabel 2. Data akumulasi Ekspor Buah-buahan

\begin{tabular}{|c|l|r|r|}
\hline No & Negara Tujuan & Netto (Ton) & Nilai FOB (Ribu US\$) \\
\hline $\mathbf{1}$ & Hongkong & $64.230,5$ & $52.598,6$ \\
\hline $\mathbf{2}$ & Tiongkok1) & $91.636,7$ & $67.332,0$ \\
\hline
\end{tabular}




\begin{tabular}{|c|l|r|r|}
\hline No & Negara Tujuan & Netto (Ton) & Nilai FOB (Ribu US\$) \\
\hline $\mathbf{3}$ & Singapura & $240.553,4$ & $193.329,7$ \\
\hline $\mathbf{4}$ & Malaysia & $111.816,7$ & $43.757,9$ \\
\hline $\mathbf{5}$ & Nepal & $131.353,3$ & $79.904,7$ \\
\hline $\mathbf{6}$ & Vietnam & $34.280,1$ & $27.371,3$ \\
\hline $\mathbf{7}$ & India & $638.307,7$ & $363.705,0$ \\
\hline $\mathbf{8}$ & Pakistan & $904.276,5$ & $619.988,7$ \\
\hline $\mathbf{9}$ & Bangladesh & $365.713,1$ & $263.084,3$ \\
\hline $\mathbf{1 0}$ & Iran & $66.203,9$ & $23.015,0$ \\
\hline $\mathbf{1 1}$ & Lainnya & $272.139,0$ & $286.458,2$ \\
\hline
\end{tabular}

Setelah diakumulasikan maka akan didapatkan nilai dari seluruh ekspor buah-buahan berdasarkan negara tujuan. Kemudian data tersebut akan masuk ke tahapan clustering dengan menerapkan algoritma $K$-Means menggunakan rapid minner untuk mengcluster data menjadi tiga cluster.

\subsection{Input Data}

Data yang telah diakumulasikan akan dimasukan ke dalam tool Rapid Minner. Sehingga dapat diclustering menjadi dua. Setelah dimasukan ke dalam Rapid Minner. Hasil akumulasi data dapat dilihat pada tabel 2.

\subsection{Centroid Data}

Dalam penerapan algoritma $K$-means dihasilkan nilai titik tengah atau centroid dari data yang didapat dengan ketentuan bahwa clusterisasi yang diinginkan adalah 3, Penentuan cluster dibagi atas tiga bagian yakni cluster tingkat ekspor tinggi ( $\mathrm{C} 1)$, cluster tingkat ekspor sedang (C2) dan cluster tingkat ekspor rendah (C3). maka nilai titik tengah atau centroid juga terdapat 3 titik. Penentuan titik cluster ini dilakukan dengan mengambil nilai terbesar (maksimum) untuk cluster tingkat ekspor tinggi (C1), nilai rata-rata (average) untuk cluster tingkat ekspor sedang (C2) dan nilai terkecil (minimum) untuk cluster tingkat ekspor rendah (C3). Nilai titik tersebut dapat diketahui pada Tabel 3 berikut:

Tabel 3. Centroid Data Awal

\begin{tabular}{|c|c|c|c|c|c|c|}
\hline Atribut & \multicolumn{2}{|c|}{ Cluster ekspor tinggi } & \multicolumn{2}{c|}{ Cluster ekspor sedang } & \multicolumn{2}{c|}{ Cluster ekspor rendah } \\
\hline \multirow{2}{*}{ Nilai } & Netto & FOB & Netto & FOB & Netto & FOB \\
\cline { 2 - 7 } & $904.276,5$ & $619.988,7$ & $272.139,0$ & $286.458,2$ & $34.280,1$ & $27.371,3$ \\
\hline
\end{tabular}

\subsection{Clustering Data}

Dengan menggunakan centroid tersebut maka dapat dicluster data yang telah didapat menjadi 3 cluster. Proses cluster dengan mengambil jarak terdekat dari setiap data yang diolah. Dari data ekspor buah-buahan menurut negara tujuan didapatkan pengelompokan pada iterasi 1 untuk 3 cluster tersebut. Cluster tingkat ekspor tinggi (C1) yakni India dan Pakistan, cluster tingkat ekspor sedang (C2) yakni Singapura, Bangladesh dan Negara lainnya dan cluster tingkat ekspor rendah (C3) yakni Hongkong, Tiongkok, Malaysia, Nepal, Vietnam dan Iran . Proses pencarian jarak terpendek, pengelompokan data pada iterasi 1 dan Clustering data dapat digambarkan pada tabel dan gambar berikut:

Tabel 4. Perhitungan jarak pusat cluster

\begin{tabular}{|c|c|r|r|r|r|r|r|}
\hline No & Negara & Netto (Ton) & FOB (Ribu US) & C1 & C2 & C3 & Jarak Terpendek \\
\hline 1 & Hongkong & $64.230,5$ & $52.598,6$ & 1013710,416 & 312915,7345 & 39159,2 & 39159,20231 \\
\hline
\end{tabular}


Techno.COM, Vol. 16, No. 4, November $2017: 348-357$

\begin{tabular}{|r|l|r|r|r|r|r|r|}
\hline No & Negara & Netto (Ton) & FOB (Ribu US) & \multicolumn{1}{c|}{ C1 } & \multicolumn{1}{c|}{ C2 } & C3 & Jarak Terpendek \\
\hline 2 & Tiongkok & $91.636,7$ & $67.332,0$ & 982757,7894 & 283896,7626 & 69904,49 & 69904,48561 \\
\hline 3 & Singapura & $240.553,4$ & $193.329,7$ & 789028,6787 & 98339,04433 & 264746,8 & 98339,04433 \\
\hline 4 & Malaysia & $111.816,7$ & $43.757,9$ & 979813,4871 & 290872,2666 & 79249,26 & 79249,25867 \\
\hline 5 & Nepal & $131.353,3$ & $79.904,7$ & 942921,5239 & 249969,9216 & 110376,5 & 110376,4661 \\
\hline 6 & Vietnam & $34.280,1$ & $27.371,3$ & 1052658,121 & 351714,1994 & 0 & 0 \\
\hline 7 & India & $638.307,7$ & $363.705,0$ & 369351,7801 & 374227,9853 & 691353,5 & 369351,7801 \\
\hline 8 & Pakistan & $904.276,5$ & $619.988,7$ & 0 & 714731,0077 & 1052658 & 0 \\
\hline 9 & Bangladesh & $365.713,1$ & $263.084,3$ & 646089,2249 & 96449,21665 & 406704,4 & 96449,21665 \\
\hline 10 & Iran & $66.203,9$ & $23.015,0$ & 1028952,517 & 334382,3934 & 32219,66 & 32219,65791 \\
\hline 11 & Lainnya & $272.139,0$ & $286.458,2$ & 714731,0077 & 0 & 351714,2 & 0 \\
\hline
\end{tabular}

Tabel 5. Pengelompakan data iterasi 1

\begin{tabular}{|c|l|c|c|c|}
\hline No. & \multicolumn{1}{|c|}{ Negara } & C1 & C2 & C3 \\
\hline 1 & Hongkong & & & 1 \\
\hline 2 & Tiongkok & & & 1 \\
\hline 3 & Singapura & & 1 & \\
\hline 4 & Malaysia & & & 1 \\
\hline 5 & Nepal & & & 1 \\
\hline 6 & Vietnam & & & 1 \\
\hline 7 & India & 1 & & \\
\hline 8 & Pakistan & 1 & & \\
\hline 9 & Bangladesh & & 1 & \\
\hline 10 & Iran & & & 1 \\
\hline 11 & Lainnya & & 1 & \\
\hline
\end{tabular}

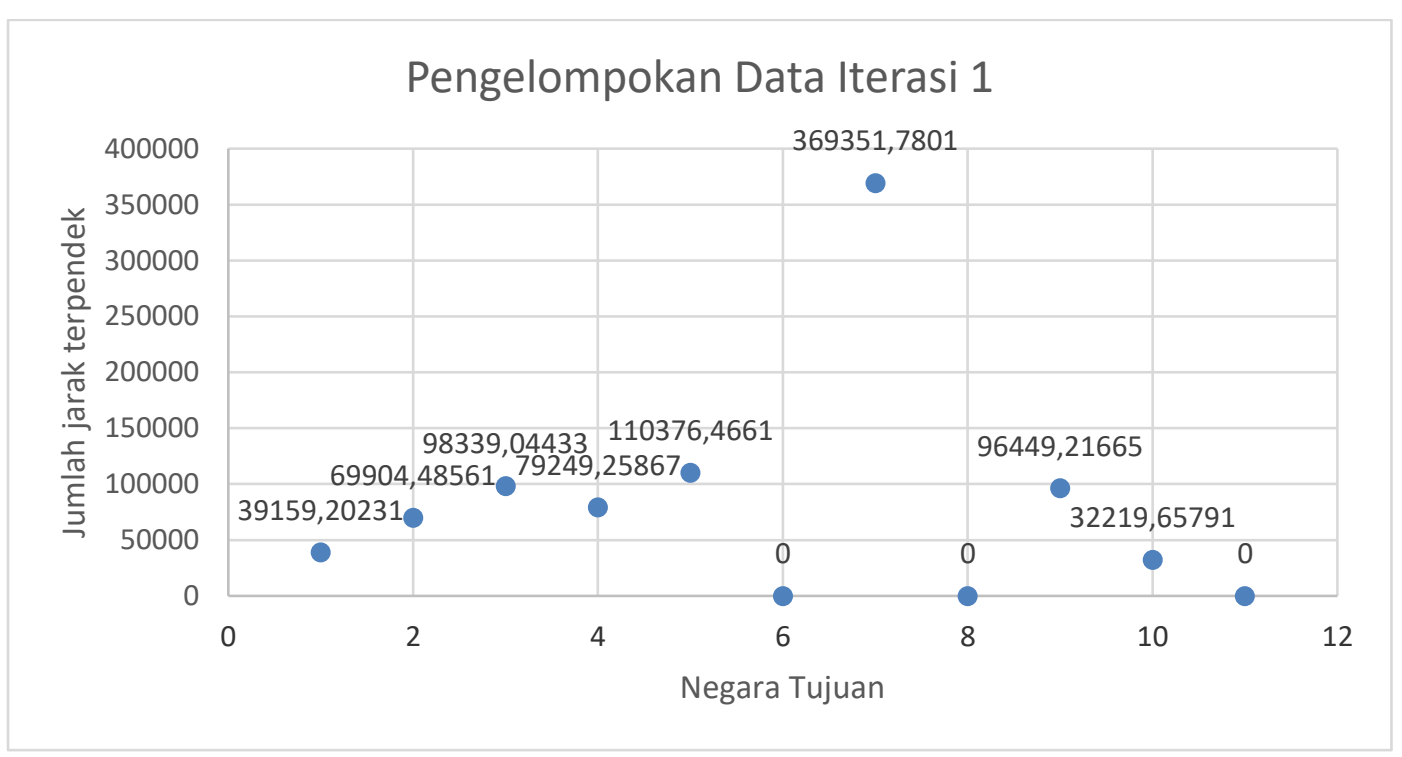




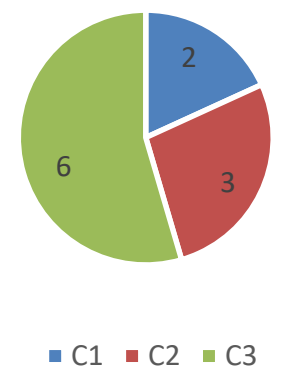

Gambar 2. Clustering Data

Proses $K$-Means akan terus beriterasi sampai pengelompokan data sama dengan pengelompokan data iterasi sebelumnya. Dengan kata lain, proses akan terus melakukan iterasi sampai data pada iterasi terakhir sama dengan iterasi sebelumnya. Pada iterasi 1 diperoleh cluster data ekspor buah-buahan pada negara tujuan, yang dapat dilihat pada gambar 2. Pada iterasi 2, akan dilakukan proses nilai titik tengah atau centroid untuk iterasi 2 dapat diketahui pada Tabel 6 berikut :

Tabel 6. Centroid Data iterasi 2

\begin{tabular}{|c|c|c|c|c|c|c|}
\hline Atribut & \multicolumn{2}{|c|}{ Cluster ekspor tinggi } & \multicolumn{2}{c|}{ Cluster ekspor sedang } & \multicolumn{2}{c|}{ Cluster ekspor rendah } \\
\hline \multirow{2}{*}{ Nilai } & Netto & FOB & Netto & FOB & Netto & FOB \\
\cline { 2 - 7 } & 771292,1 & 491846,85 & 292801,8333 & 247624,0667 & 83253,53333 & 48996,58333 \\
\hline
\end{tabular}

Setelah mendapatkan nilai titik tengah atau centroid, proses sama dilakukan dengan mencari jarak terdekat. Proses pencarian jarak terpendek, pengelompokan data pada iterasi 2 dan Clustering data dapat digambarkan pada tabel dan gambar berikut:

Tabel 7. Perhitungan jarak pusat cluster iterasi 2

\begin{tabular}{|c|l|r|r|r|r|r|r|}
\hline No & Negara & Netto (Ton) & FOB (Ribu US) & \multicolumn{1}{c|}{ C1 } & \multicolumn{1}{c|}{ C2 } & \multicolumn{1}{c|}{ C3 } & Jarak Terpendek \\
\hline 1 & Hongkong & $64.230,5$ & $52.598,6$ & 832391,2 & 300465,9 & 19361,05 & 19361,05166 \\
\hline 2 & Tiongkok & $91.636,7$ & $67.332,0$ & 801339,1 & 270134,5 & 20160,98 & 20160,97685 \\
\hline 3 & Singapura & $240.553,4$ & $193.329,7$ & 608930,3 & 75351,03 & 213483,7 & 75351,02546 \\
\hline 4 & Malaysia & $111.816,7$ & $43.757,9$ & 797302,6 & 272611,5 & 29039,6 & 29039,59871 \\
\hline 5 & Nepal & $131.353,3$ & $79.904,7$ & 761063,7 & 232799,1 & 57174,29 & 57174,28818 \\
\hline 6 & Vietnam & $34.280,1$ & $27.371,3$ & 871162,6 & 339624,5 & 53535,5 & 53535,50272 \\
\hline 7 & India & $638.307,7$ & $363.705,0$ & 184675,9 & 364484,7 & 638064,7 & 184675,89 \\
\hline 8 & Pakistan & $904.276,5$ & $619.988,7$ & 184675,9 & 715930,6 & 1000055 & 184675,89 \\
\hline 9 & Bangladesh & $365.713,1$ & $263.084,3$ & 465646,5 & 74532,35 & 354424,8 & 74532,35285 \\
\hline 10 & Iran & $66.203,9$ & $23.015,0$ & 846730,6 & 319054,6 & 31076,24 & 31076,23963 \\
\hline 11 & Lainnya & $272.139,0$ & $286.458,2$ & 539757,6 & 43989,12 & 303423,4 & 43989,11903 \\
\hline
\end{tabular}

Tabel 8. Pengelompakan data iterasi 2

\begin{tabular}{|c|l|c|c|c|}
\hline No. & Negara & C1 & C2 & C3 \\
\hline 1 & Hongkong & & & 1 \\
\hline 2 & Tiongkok & & & 1 \\
\hline 3 & Singapura & & 1 & \\
\hline
\end{tabular}




\begin{tabular}{|c|l|c|c|c|}
\hline No. & \multicolumn{1}{|c|}{ Negara } & C1 & C2 & C3 \\
\hline 4 & Malaysia & & & 1 \\
\hline 5 & Nepal & & & 1 \\
\hline 6 & Vietnam & & & 1 \\
\hline 7 & India & 1 & & \\
\hline 8 & Pakistan & 1 & & \\
\hline 9 & Bangladesh & & 1 & \\
\hline 10 & Iran & & & 1 \\
\hline 11 & Lainnya & & 1 & \\
\hline
\end{tabular}
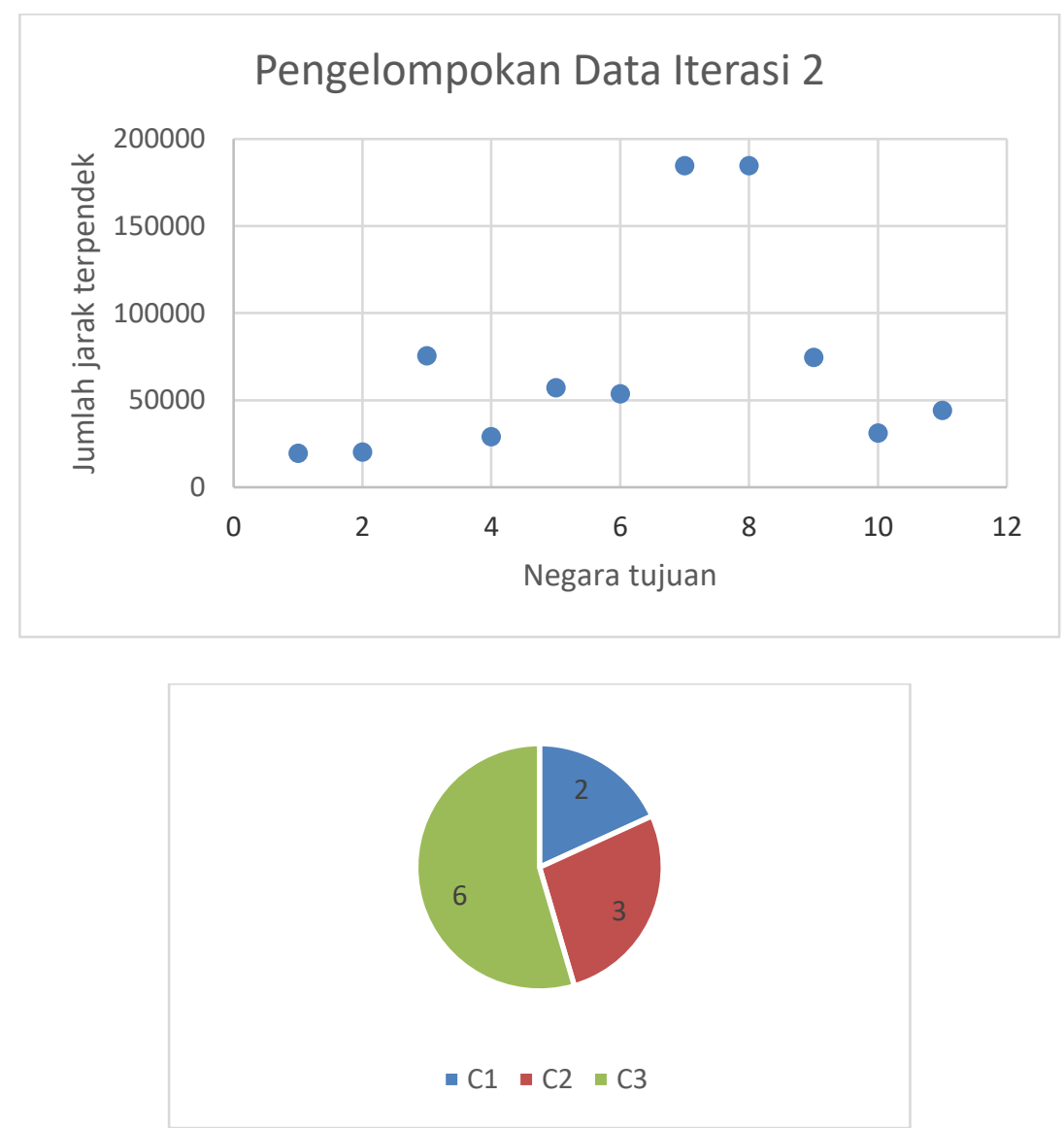

Gambar 3. Clustering Data Iterasi 2

\subsection{Analisa Data}

Pada iterasi 2, pengelompokan data yang dilakukan terhadap 3 cluster dengan iterasi 1 didapatkan hasil yang sama. Dari 11 data ekspor buah-buahan berdasarkan negara tujuan dapat dikertahui, 2 negara cluster tingkat ekspor tinggi yakni India dan Pakistan, 3 negara cluster tingkat ekspor sedang yakni Singapura, Bangladesh dan Negara lainnya dan 6 negara cluster tingkat ekspor rendah yakni Hongkong, Tiongkok, Malaysia, Nepal, Vietnam dan Iran 


\section{KESIMPULAN}

Untuk melakukan penilaian terhadap hasil ekspor buah-buahan berdasarkan negara tujuan dapat menerapkan metode clustering K-Means. Data diolah untuk memperolah nilai dari produksi ekspor buah-buahan berdasarkan negara tujuan. Data tersebut diolah menggunakan Rapidminner untuk ditentukan nilai centroid dalam 3 cluster yaitu cluster tingkat ekspor tinggi, cluster tingkat ekspor sedang dan cluster tingkat ekspor rendah. Cetroid data untuk cluster tingkat ekspor tinggi 904.276,5, Cetroid data untuk cluster tingkat ekspor sedang 265.501 dan Cetroid data untuk cluster tingkat ekspor rendah 34.280,1. Sehingga diperoleh penilaian berdasarkan indeks ekspor buah-buahan dengan 2 negara cluster tingkat ekspor tinggi yakni India dan Pakistan, 3 negara cluster tingkat ekspor sedang yakni Singapura, Bangladesh dan Negara lainnya dan 6 negara cluster tingkat ekspor rendah yakni Hongkong, Tiongkok, Malaysia, Nepal, Vietnam dan Iran. Hasil yang dari penelitian dapat digunakan untuk mengetahui jumlah ekspor buah-buahan menurut negara tujuan.

\section{SARAN}

Dalam pengolahan data untuk clustering bisa memberikan pembobotan kriteria agar data yang dihasilkan lebih akurat. Selain itu, juga perlu meningkatan akurasi clustering pada data. Penambahan kriteria dapat dilakukan guna mendapatkan hasil yang lebih akurat dalam proses clustering.

\section{UCAPAN TERIMA KASIH}

Terima kasih kepada program studi Sistem Informasi, STIKOM Tunas Bangsa Pematangsiantar tas dukungan dalam terlaksanakannya penelitian ini.

\section{DAFTAR PUSTAKA}

[1] S. M. S. Hadi Rachmat, Anindya Apriliyanti Pravitasari, "Fuzzy K-Means Clustering Untuk Mengklasifikasikan Perusahaan Eksportir Furniture Rotan Di Kabupaten Cirebon," Pros. Semin. Nas. Stat., vol. 2010, no. November, pp. 146-153, 2010.

[2] S. Nelson Butarbutar, Agus Perdana Windarto, Dedi Hartama, "Komparasi Kinerja Algoritma Fuzzy C-Means Dan K-Means Dalam Pengelompokan Data Siswa Berdasarkan Prestasi Nilaia Kademik Siswa," JURASIK (Jurnal Ris. Sist. Inf. Tek. Inform., vol. 1, no. 2012, pp. 46-55, 2016.

[3] Wyatt, J. C, danSpiegelhalter, D., 1991, Field Trials of Medical Decision-Aids: PotentialProblems and Solutions, Clayton, P. (ed.): Proc. 15th Symposium on ComputerApplications in Medical Care, Vol 1, Ed. 2, McGraw Hill Inc, New York.

[4] Yusoff, M, Rahman, S.,A., Mutalib, S., and Mohammed, A. , 2006, Diagnosing Application Development for Skin Disease Using Backpropagation Neural Network Technique, Journal of Information Technology, vol 18, hal 152-159.

[5] M. K. Aldi Nurzahputra, Much Aziz Muslim, "Penerapan Algoritma K-Means Untuk Clustering Penilaian Dosen Berdasarkan Indeks Kepuasan Mahasiswa," Techno.COM, vol. 16, no. 1, pp. 17-24, 2017. 
[6] Venkateswarlu, B., \& Raju, P. G., 2013, Mine Blood Donors Information through Improved KMeans Clustering, arXiv preprint arXiv:1309.2597.

[7] Hermawati, F. A., 2013, Data Mining, Penerbit ANDI, Yogyakarta.

[8] Soni, N., \& Ganatra, A., 2012, Categorization of several Clustering algorithms from different perspective: a review, International Journal of Advanced Research in Computer Science and Software Engineering, 2(8), 63-68. 